\title{
The Reflective Dispositional Coaching Process: An Action Research Project
}

Edwin D. Bell, (E-mail: belle@wssu.edu), Winston-Salem State University

Kathy Grant, Winston-Salem State University

Patricia Fisk-Moody, Winston-Salem State University

\begin{abstract}
The authors implemented an action research project to help teacher education candidates to reflect upon, assess, and ultimately strengthen teacher candidate dispositions through the Reflective Dispositional Coaching Model. The teacher education faculty agreed that candidate dispositions should address four areas: (a) professionalism, (b) commitment to lifelong learning, (c) reflective and critical thinker, and (d) commitment to diversity. Coaching the candidates through the reflective practitioner model not only allowed the candidates to operationally define and assess their dispositions, but also assisted them in a plan for empowerment and professional growth.
\end{abstract}

\section{INTRODUCTION}

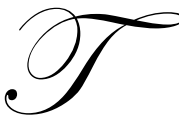

he Council of State School Officers (INTASC, 1992) identified candidate dispositions as a necessary condition for effective beginning teachers. Two of authors were involved in a faculty committee that examined the conceptual framework for teacher education as part of the National Association of Teacher Education (NCATE) self-study process. The first step of that process was an examination of the research literature, relevant national standards, and our existing procedures. This first step indicated that we did explicitly address dispositions in our teacher education curriculum.

The authors chose to implement an action research project (Stringer, 2004) through the implementation of the reflection practitioner model (Schon, 1987, 1983) in the capstone course of the teacher education program, ELE 4333 - Responsive Pedagogy.

The faculty implemented a four-part process to help teacher education candidates to reflect upon, assess, and ultimately strengthen their dispositions through a reflective practitioner model. The progression through modes of dispositional adjustment and fine-tuning nurtured growth-oriented beliefs for both the teacher candidates and faculty. Cohesion between the Winston-Salem State University, WSSU, Reflective Practitioner Model and the WSSU teacher education conceptual framework was further sustained by teacher candidate suggestions for curricular foci. Crucial in the process was a form of dispositional coaching with candidates to develop an action plan for the candidates' perceived dispositional weaknesses.

\section{Relevant Literature}

Wang, Haertel, and Walberg (1993a) in their meta-analysis of 50 years of research on student learning stated that three key proximal variables have the most influence on student learning: psychological, instructional, and home environment. They reported that "When averaged together, the different kinds of classroom instruction and climate had nearly as much impact on student learning as student aptitude categories" (Wang, Haertel, and Walberg, 1993b, pp.75-76).

The Interstate New Teacher Assessment and Support Consortium (INTASC, 1992), which worked on the development of standards for new teachers, placed professional responsibility and commitment to reflection on personal and professional practice as part of the foundation of effective teaching. The policy research on teacher 
preparation by Linda Darling-Hammond (1992, 2000a, 2000b), the chairperson of the drafting committee for the INTASC standards, emphasized the importance of effective teacher preparation and their commitment to professionalism in the development of the knowledge, skills, and dispositions, i.e., the theory-in-use (Argyris And Schon, 1978), that guide their behaviors. In addition, Sanders' (2000) work on value-added assessment of teachers clearly documented not only the positive, but also the negative impact that teacher effectiveness has on students.

Argyris and Schon (1978) argued that individuals may be unaware of the contradictions between their espoused theory of action and their actual theory-in-use. Smith's (2001) description of Donald Schon's work on the reflective practitioner helped the teacher education faculty understand that pre-service teachers' ability to reflect on their professional practice is a necessary condition for the level of knowledge, skill, and dispositions that we expect of them.

\section{Reflective Practitioner}

Donald Schon (1987) made this point when he addressed that American Educational Research Association (AERA) annual meeting:

The challenge to the professional schools, I think, is this challenge of educating for artistry. Helping people become more competent in the indeterminate zones of practice, at carrying out processes of reflection-in-action, and reflection on reflection-in-action, and helping them to coordinate that artistry with applied science, because I'm not arguing that applied science should be thrown out the window. I'm arguing that it has a special zone of relevance which depends on our ability to do these other things, on the one hand to set problems in ways that the categories of applied science can fix and fit and, on the other hand, to fill with art the gap between theory and technique and concrete action. (par. 17)

The WSSU teacher education curriculum should be able to help teachers learn to reflect on the application of their own knowledge, skills, dispositions, and the results that those variables produce in student learning.

Schon's (1983) model of reflective practice is a type of disciplined inquiry that not only tests data against assumptions and projections, but also tests the assumptions themselves when data does not conform to the theory-ofaction that is utilized.

\section{Dispositions}

Freeman (2004) believed that changing dispositions, i.e., what teachers believe about and can see in themselves and their students, is central to increasing teacher effectiveness with all students. The combination of one's knowledge, skills, and dispositions actually determine what one sees and pays attention to in the environment. A teacher cannot impact something that she/he cannot see or comprehend. Wasicsko, Callahan, \& Wirtz (2004) emphasized the importance of tying the dispositions to the conceptual framework guiding a program's curriculum. Raths (2001) discussed some of the strategies that can be used to help teach dispositions. In addition, Damon (2005) cautioned against using dispositions to enforce the political beliefs of those conducting the assessments and the importance of tying dispositions to operational behavior that enhances the teaching and learning process.

The authors chose to integrate the reflective practitioner model (Schon 1987; Schon, 1983; Smith, 2001) with Raths' (2001) strategy for confronting the candidate with dissonance, along with Freeman's (2004) suggestion that faculty members serve as coaches as our theory-of-action for this case study. We wanted the candidates to operationally define the behavior that they believed provided evidence for the deficiency or mastery of a particular disposition.

\section{Background}

Winston-Salem State University (WSSU) is a historically Black university in the University of North Carolina system with a long history in teacher education. "WSSU is the first historically black institution in the nation 
to award elementary education degrees to African American teachers” (WSSU, 2003-2005, p. 2007). The WSSU teacher education program is committed to developing a diverse, knowledgeable, and skilled faculty who can implement a strong curriculum that enables graduates of the teacher education program to effectively educate all students. Candidates in a teacher education program should possess the dispositions to interact effectively with students, families, communities, and colleagues as they "depart to serve.”

Pilot of the Reflective Practitioner Model

For Winston-Salem State University

School of Education

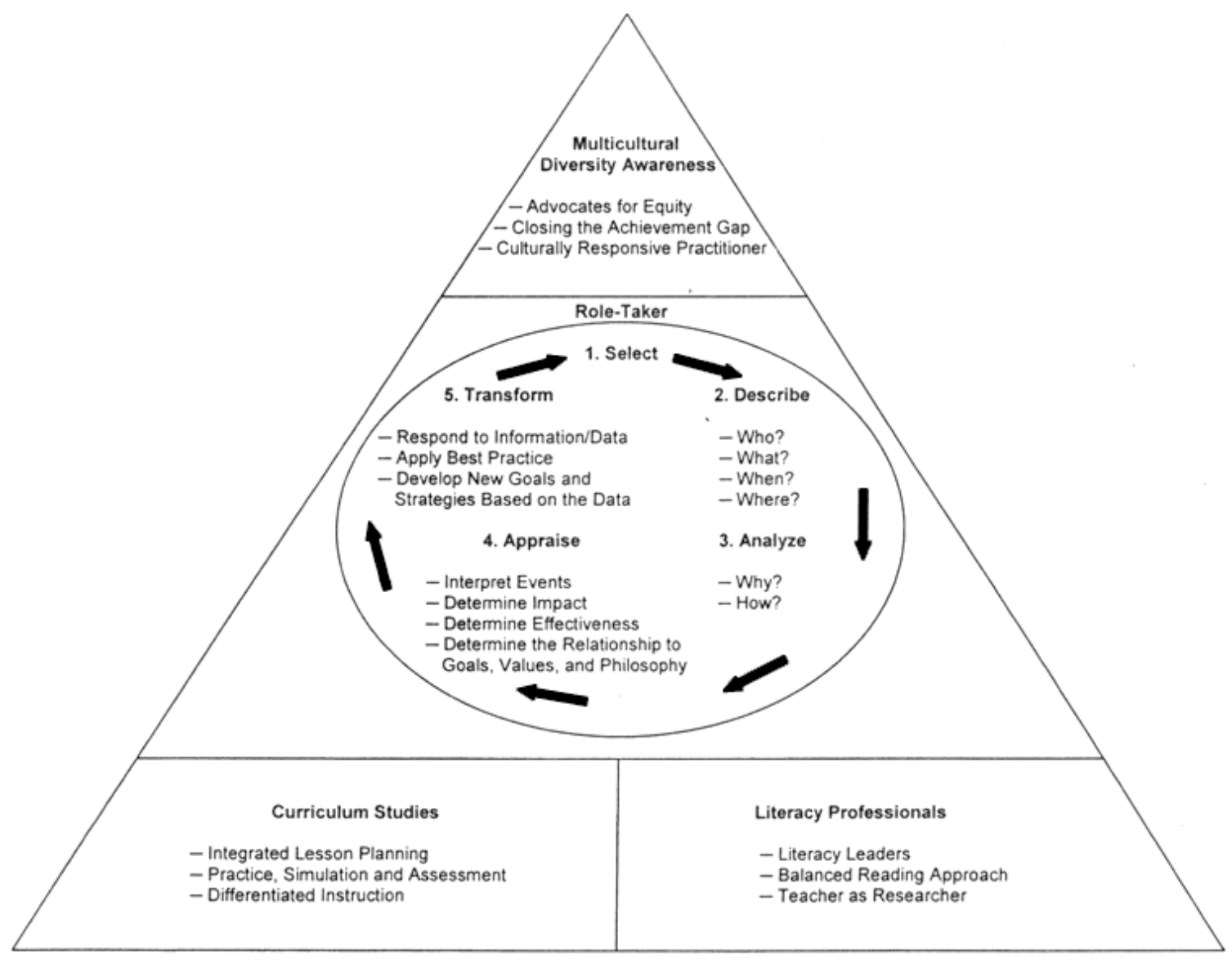

Figure 1. WSSU Reflective Practitioner Model 


\section{The WSSU Reflective Practitioner Model}

The emergence of a Reflective Practitioner Model based on the Winston-Salem State School of Education Conceptual Framework was generated through deep thought, discussion, and consensus in the senior level capstone course Responsive Pedagogy. Teacher candidates were challenged to identify several focus areas that, as graduates of WSSU, they felt were essential to their continued growth as beginning teachers. The three areas agreed upon by the group included multicultural diversity awareness, curriculum studies, and literacy professionals. The finalized WSSU Reflective Practitioner Model is represented by Figure 1. Within the three selected areas, the candidate selects an area of emphasis, describes the relevant behavior in detail, analyzes the behavior, appraises the behavior, develops a plan for growth, and then begins the cycle again. This model is utilized as the framework for reflective writing throughout the course whose culminating product is a senior level teacher education portfolio.

\section{METHODOLOGY}

\section{Sample}

The sample for this action research intervention was 35 students in ELE 4333 - Responsive pedagogy over two semesters. Two of the authors co-taught this course.

\section{The Research Question}

There was one question for this action research: What impact did the implementation of the reflective practioners model have on the development of teacher education candidates' dispositions?

\section{The Intervention - The WSSU Dispositional Model}

Education students enrolled in a senior level Responsive Pedagogy course completed a reflective practitioner self-assessment of teacher candidate dispositions based on four broad elements of the Winston-Salem State University's conceptual framework. The proficiencies included: (a) professionalism, (b) commitment to lifelong learning, (c) reflective and critical thinker, and (d) commitment to diversity. The broad proficiencies were further broken down into specific areas of focus.

From the assessment, students identified a dispositional strength and a weakness. The students were then asked to use the reflective practitioner model as a framework to develop a plan of action to change the identified weakness into a strength. Using the written reflection as a guide, students held three professional disposition conferences with a coach; one at the beginning of the course, one at midterm, and one at the completion of the course, to support student growth in the identified area of weakness.

\section{Data Collection And Analysis}

The authors collected data through triangulation (Mills, 2007) from the teacher education candidates, i.e., we used three methods: surveys, work products, and interviews, to collect data from the one data source. The authors conducted a content analysis (Silverman, 2004) of the data derived from the three methods.

\section{THE RESULTS OF THE CASE STUDY}

During the first of three conferences, and at the beginning of the 15-week student teaching experience, the student and coach discussed identified strengths from a list of teacher candidate dispositions and the student provided evidence to support the strengths in those areas. Believing that good teachers act in certain ways, the student teachers are placed in teaching environments with teachers who model appropriate teacher dispositions, while the coach works with the student to strengthen dispositions that will enable the beginner teacher to have the needed skill sets to be successful in the classroom; growth oriented skills are discussed. Thus, the student also identified a dispositional 
weakness and together with the coach developed an action plan to change the stated dispositional weakness into strengths.

In a second conference held at midterm, student and coach discussed progress in strengthening the dispositional weakness and student provided evidence in the form of ongoing journaling to support this growth. These individual conferences were held outside the classroom setting and provided the student and coach with the opportunity to develop a relationship where the student felt comfortable sharing personal attitudes and beliefs about teaching and learning and asked questions to help overcome perceived roadblocks to change.

Using the Reflective Practitioner Model, the third conference at the end of the course focused not only on tangible evidence of growth in the teacher candidate's dispositional weakness, but also gave an opportunity for the student and coach to talk about the reflective practioners model had worked on the growth and development of dispositions. Tangible evidence took the form of experiential journals, lesson plans, and letters of support from administrators, teachers, and parents. Other evidence included attendance at workshops on diversity, leadership, and literacy. Portfolios, literature reviews, and self-produced classroom videos of their teaching experiences were also considered artifacts. One student developed a webpage for the local chapter of Kappa Delta Pi to support her leadership enhancement; while another candidate developed autograph boards to document student involvement in activities.

The student/coach dialogue process was reflective in nature and was a give and take experience in which the student opened up to the coach and several personal milestones were revealed. The student teachers commonly commented that they learned relationship building skills through this rigorous self-examination. A spirit of openmindedness towards dispositional change was stressed.

Overall, students commented that focusing on dispositional strengths and the weaknesses during the student teaching experience was highly effective and made them more sensitive to the needs of their students in the classroom and additionally helped validate themselves as teachers.

The analysis of candidate surveys, candidate products, and candidate interviews suggests that the intervention, the WSSU Reflective Practitioner Model, had a positive impact on the development of teacher education candidates' dispositions

\section{CONTINUING THE PROCESS}

We believe that the integration of the self-assessment of dispositions into a model of reflective practice is a valuable tool for the development of teachers who will be able to develop the knowledge, skills, and dispositions that will enable them to be effective with all types of students. New teachers will need continued dispositional coaching on reflection during their induction period as they are challenged by the issues of teaching. In those settings, we hope to conduct a longitudinal analysis of the impact of purposeful reflective teaching as impacting increased teacher effectiveness.

We encourage teacher educators to consider the use of a reflective process model including dispositional coaching as they integrate the INTASC standards into the assessment process for their candidates and their programs. 


\section{REFERENCES}

1. Argyris, C. and Schon, D. A. (1978). Organizational Learning: A Theory of Action Perspective. Reading, MA: Addison-Wesley Publishing Company.

2. Damon, W. (2005, September). Personality Tests: The dispositional dispute in teacher preparation today, and what to do about it. Thomas B. Fordham Foundation. Retrieved June 8, 2006 from http://www.edexcellence.net/foundation/publication/publication.cfm?id=343

3. Darling-Hammond, L. (2000a). New standards and old inequalities: School reform and the education of African-American students. Journal of Negro Education, 69(4), 263-287.

4. Darling-Hammond, L. (2000b, January). Teacher quality and student achievement: A review of state policy evidence. Educational Policy analysis, 8(1). (Retrieved June 8, 2006 from http://epaa.asu.edu/epaa/v8n1/).

5. Darling-Hammond, L. (1992). Teaching and knowledge: Policy issues posed by alternate certification for teachers. In W. D. Hawley (Ed.), The alternative certification of teachers. Washington, DC: ERIC Clearinghouse on Teacher Education

6. Freeman, L. (2004, February 9). Dispositions in teacher education: Some unresolved issues. Association of American Colleges of Teacher Education, Annual Meeting.

7. Interstate New Teacher Assessment and Support Consortium, (1992). Model Standards for Beginning Teacher Licensing, assessment, and Development: A Resource for State Dialogue. Washington, DC: Council of Chief State School Officers.

8. Mills, G. E. (2007). Action Research: A Guide for the Teacher Researcher, $3^{\text {rd }}$ Edition. Upper Saddle, NJ: Pearson, Merrill, Prentice-Hall.

9. Sanders, W. L. (2000). Value-added assessment from student achievement data: Opportunities and hurdles. Journal of Personnel Evaluation in Education, (14)4, 329-339.

10. Schon, D. A. (1987). Educating the reflective practitioner. Presentation at the American Educational Research Association, Annual Meeting, Washington, D. C. Retrieved June 8, 2006 from http://educ.queensu.ca/ ar/schon87.htm

11. Schon, D. A. (1983). The reflective practitioner: How professionals think in action. New York, NY: Basic Books.

12. Silverman, D. (2004). Qualitative Research: Theory, Method, and Practice, $2^{\text {nd }}$ Edition. Thousand Oaks, CA: Sage Publishing.

13. Smith, M. K. (2001). 'Donald Schön: learning, reflection and change', the encyclopedia of informal education, Retrieved June 8, 2006 from www.infed.org/thinkers/et-schon.htm

14. Stringer, E. T. (2004). Action Research in Education. Upper Saddle, NJ: Pearson; Merrill, Prentice-Hall.

15. Wang, M. C., Haertel, G. D., \& Walberg, H. J. (1993a, Fall). Toward a knowledge base for school learning. Review of Educational Research, 63(3), 249-294

16. Wang, M. C., Haertel, G. D., Wlaberg, H. J (1993b, December/1994, January). What helps students learn? Educational Leadership, 51(4), 74-79

17. Wasicsko, M. M., Callhan, C. J., and Wirtz, P. (2004, Fall). Integrating dispositions into the conceptual framework four a priori questions. KVA Journal, 23(1), 1-8.

18. Winston-Salem State University (2003-2005). Undergraduate Catalog. Winston-Salem, NC: Author. 